International Journal of Medical Sciences

ISSN 1449-1907 www.medsci.org 2006 3(1):14-20

Research paper

\title{
Correlations of HBV Genotypes, Mutations Affecting HBeAg Expression and HBeAg/ anti-HBe Status in HBV Carriers
}

\author{
Chee Kent Lim ${ }^{12}$, Joanne Tsui Ming Tan ${ }^{3}$, Jason Boo Siang Khoo ${ }^{4}$, Aarthi Ravichandran ${ }^{5}$, Hsin Mei Low ${ }^{6}$, Yin Chyi Chan ${ }^{1}$ \\ and So Har Ton 1 \\ 1. School of Arts and Sciences, Monash University Malaysia, Petaling Jaya 46150, Malaysia \\ 2. Faculty of Biotechnology, Malaysia University of Science and Technology, Petaling Jaya 47301, Malaysia \\ 3. Discipline of Medicine, Blackburn Building D06, University of Sydney, NSW 2006, Australia \\ 4. Institute of Molecular and Cell Biology, 61 Biopolis Drive (Proteos), 138673, Singapore \\ 5. Department of Biological Sciences, Faculty of Sciences, National University of Singapore, 10 Kent Ridge Crescent, 119260 , \\ Singapore \\ 6. Faculty of Medicine, Nursing and Health Sciences, Monash Immunology and Stem Cell Laboratories, Level 3, STRIP 1 - \\ Building 75, Monash University, Wellington Road, Clayton, VIC 3800, Australia
}

Corresponding address: Dr. So Har Ton, E-mail: ton.so.ha@artsci.monash.edu.my; telephone + (603) 56360600 Ext 3526; fax + (603) 56358640

Received: 2005.09.25; Accepted: 2005.12.15; Published: 2006.01.01

This study was carried out to determine the effects of hepatitis $\mathrm{B}$ virus genotypes, core promoter mutations $\left(\mathrm{A}^{1762} \mathrm{G}^{1764} \rightarrow \mathrm{T}^{1762} \mathrm{~A}^{1764}\right)$ as well as precore stop codon mutations (TGG $\left.\rightarrow \mathrm{T} \underline{\mathrm{A}} \mathrm{G}\right)$ on HBeAg expression and HBeAg/ antiHBe status. Study was also performed on the effects of codon 15 variants $\left(\mathrm{C}^{1858} / \mathrm{T}^{1858}\right)$ on the predisposition of precore stop codon mutations (TGG $\rightarrow$ TAG). A total of 77 sera samples were analyzed. Fifty one samples were successfully genotyped of which the predominant genotype was genotype B (29/51, 56.9 \%), followed by genotype C (16/ 51 , 31.4 $\%$ ). Co-infections by genotypes $\mathrm{B}$ and $\mathrm{C}$ were observed in four samples $(7.8 \%)$. To a lesser degree, genotypes $\mathrm{D}$ and $\mathrm{E}$ $\left(2.0 \%\right.$ each) were also observed. For core promoter mutations, the prevalence was $68.8 \%$ (53/ 77) for $\mathrm{A}^{1762} \mathrm{G}^{1764}$ wildtype and $14.3 \%(11 / 77)$ for $\mathrm{T}^{1762} \mathrm{~A}^{1764}$ mutant while $9.1 \%$ (7/ 77) was co-infected by both strains. The prevalence of codon 15 variants was found to be $42.9 \%$ (33/ 77) for T1858 variant and $16.9 \%$ (13/ 77) for C1858 variant. No TAG mutation was found. In our study, no associations were found between genotypes (B and C) and core promoter mutations as well as codon 15 variants. Also no correlation was observed between $\mathrm{HBeAg} /$ anti-HBe status with genotypes ( $\mathrm{B}$ and $\mathrm{C}$ ) and core promoter mutations.

Key words: HBV, Genotypes, HBeAg, Core Promoter Mutation, 1858 Variants, Precore Stop Codon Mutation

\section{Introduction}

The hepatitis B virus (HBV) is currently categorized into eight genotypes (A to $\mathrm{H}$ ). The HBV genotyping system was first introduced by Okamoto et al. [23] with four genotypic groups (A to D) distinguished by $8.0 \%$ threshold divergence between the genomes of $\mathrm{HBV}$. Subsequently, the genotypes were extended to include genotypes E, F, G and $\mathrm{H}[3,21,29]$. Thus, currently there are 8 accepted genotypes (A to $\mathrm{H}$ ) for HBV.

Genotypes have been found to be geographically distributed. Genotype A is predominant in Northern Europe and North America. Genotypes B and C are observed mainly in Asia including China, Japan and South-east Asian regions. The Mediterranean region has genotype D as the most prevalent strain. Genotype E is localized mainly in parts of East, Central and West Africa. As for genotype F, it is found mainly in South and Central Americas [21]. So far, genotype $G$ has been found in the USA and France [29]. Genotype $\mathrm{H}$ is found in Central America [3].

The presence of Hepatitis B e antigen (HBeAg) in the serum is used as a serological marker that correlates with the presence of viral replication with liver damage occurring. As HBeAg disappears from the serum, antibody to HBeAg (anti-HBe) will become detectable. The appearance of anti-HBe in the blood stream indicates biochemical and histological improvement of the liver injury with decreased viral detection. However, as antiHBe becomes prominent, the wild-type viral population will be replaced by mutants that do not produce or have decreased HBeAg expression. These mutants may be advantageously selected for by the anti-viral activity of the anti-HBe. The fact that HBV genome has a very high mutation rate which is estimated to be $10^{4}$ fold higher than the human genome or at an estimated range of 1-10 $\times 10^{-5}$ per site per year may also support the occurrence of the mutants [24, 27].

A few mutations in the HBV genome could affect HBeAg production. The two which are widely studied are the core promoter dual mutations $\left(\mathrm{A}^{1762} \mathrm{G}^{1764} \rightarrow \mathrm{T}^{1762} \mathrm{~A}^{1764}\right)$ and precore stop codon mutations (TGG $\rightarrow$ T $\underline{A G}$ ). The core promoter mutations are located within the DNA regulatory element that binds to nuclear binding protein [32]. This region is located upstream of the transcriptional start sites for precore-mRNA and the pregenomic RNA (pgRNA) [37]. The transcript of $3.5 \mathrm{~kb}$ precore-mRNA is responsible for the translation of $\mathrm{HBeAg}$ while the $3.4 \mathrm{~kb}$ pgRNA transcript is used for viral core protein production and also serves as the template for viral DNA replication. These dual mutations could decrease the transcription of the precore-mRNA which is the precursor RNA template for the production of HBeAg but ironically increases the viral replicative capability as transcription of the pgRNA is enhanced [19]. 
As for the precore stop codon mutation (TGG $\rightarrow$ T $\underline{A} G$ ) at codon 28 of the precore/ core gene, it is a mutation that occurs in the nucleotide position of 1896, substituting guanine to adenine [4]. It is a nonsense mutation that converts tryptophan to a stop codon in the precore segment of the precore/ core gene. This will abort the translation of HBeAg. As HBeAg does not form part of the viral particle, it can be dispensed without affecting the formation of the viral particles.

Although not involved in $\mathrm{HBeAg}$ production directly, codon 15 variants $\left(\mathrm{C}^{1858} / \mathrm{T}^{1858}\right)$ are significant as they are involved in base pair bonding with nucleotide 1896 in the secondary loop structure of the pgRNA [33]. This loop structure functions as an encapsidation signal which recruits the HBV polymerase for the synthesis of HBV genome. The occurrence of cytosine at nucleotide 1858 ( $\mathrm{C}^{1858}$ variant) prevents the stable formation of precore stop codon mutation (TGG $\rightarrow$ T $\underline{A G}$ ) due to the weak binding force with adenine at nucleotide 1896, thus destabilizing the secondary loop structure. Whereas thymine at nucleotide 1858 ( ( 1858 variant) allows flexibility in that it can stably bonds with adenine at nucleotide 1896 and so resulting in precore stop codon mutation (TGG $\rightarrow$ TAG) but can also wobble pairs with guanine at nucleotide 1896 in the TGG wild-type without disrupting the secondary loop structure [17].

A number of reports have been published on the correlations between HBV genotypes, core promoter mutations $\left(\mathrm{A}^{1762} \mathrm{G}^{1764} \rightarrow \mathrm{T}^{1762} \mathrm{~A}^{1764}\right)$, precore stop codon mutations (TGG $\rightarrow$ TAG $)$, codon 15 variants $\left(\mathrm{C}^{1858} / \mathrm{T}^{1858}\right.$ ) and $\mathrm{HBeAg} /$ anti-HBe status but conflicting results have been observed. Therefore, it is our interest to examine these correlations in HBV originated from Malaysian carriers.

\section{Materials and Methods}

\section{Samples}

A total of 77 sera samples infected with HBV were used in this study. Samples were collected from the Tengku Ampuan Rahimah Hospital, Klang, Malaysia, Sunway Medical Center, Malaysia and Hospital Universiti Kebangsaan, Malaysia. The HBV carriers were diagnosed through routine blood screening for hepatitis B surface antigen (HBsAg) and were tested positive for HBsAg for more than 6 months of repeated testing. Sera samples were withdrawn from infected individuals using sterile syringes and were stored in individual blood collection tubes to avoid cross-contamination. These were kept at -70 ${ }^{\circ} \mathrm{C}$ until required. Patients' consents were obtained prior to study.

\section{Preparation prior to $\mathbf{P C R}$}

Samples were concentrated using Integrated SpeedVac ${ }^{\text {TM }}$ System (ISS-110) (Savant Technologies) at medium drying rate for 2 hours. Approximately $1.4 \mathrm{~mL}$ serum was concentrated to a final volume of $400 \mu \mathrm{L}$. The concentrated sera were then centrifuged for 10 minutes at $20000 \mathrm{~g}$ to separate any lipid or protein found in suspension. Subsequently, HBV nucleic acids were extracted from $200 \mu \mathrm{L}$ of the concentrated sera using High Pure Viral Nucleic Acid Kit (Roche).

\section{Genotyping using nested PCR with type specific primers}

PCR amplifications were performed using PCR Reagent System (Invitrogen). Two sets of primers developed by Naito et al. [20] were used. The first set amplified the region between pre-S and $\mathrm{S}$ regions of $\mathrm{HBV}$ genome. The amplified PCR product was then subjected to another round of PCR using the second set of primers consisting of 6 pairs of primers. Each primer pair would yield PCR product with size that corresponds to a genotype (A to F).

\section{Genotyping using PCR-RFLP on the pre-S region}

This method was performed to complement the genotyping method above in order to obtain an overall better result on the genotypes of the HBV. Primers designed by Lindh et al. [14] were used to amplify the pre$S$ region of the HBV genome using PCR Reagent System (Invitrogen). PCR products were digested separately with AvaII (New England Biolabs) and DpnII (New England Biolabs) to produce restriction fragment length polymorphism (RFLP) patterns. These patterns were compared with patterns of known genotypes (A to F) as observed by Lindh et al. [14].

\section{Core promoter mutations $\left(A^{1762} G^{1764} \rightarrow T^{1762} A^{1764}\right)$ analysis}

The method for this analysis was adapted from Takahashi et al. [32]. This method was based on the creation of Sau3AI restriction site on the PCR product if $\mathrm{T}^{1762} \mathrm{~A}^{1764}$ dual mutations were present. The PCR product amplified from $\mathrm{A}^{1762} \mathrm{G}^{1764}$ wild-type would not have the restriction site created. Subsequently, PCR products were digested with Sau3AI (New England Biolabs) and observed on $2.0 \%$ agarose gel (Promega). Digested products for $\mathrm{T}^{1762} \mathrm{~A}^{1764}$ dual mutations would yield $197 \mathrm{bp}$ and $110 \mathrm{bp}$ while $\mathrm{A}^{1762} \mathrm{G}^{1764}$ wild-type would be undigested and remained at $307 \mathrm{bp}$.

\section{Codon 15 variants $\left(C^{1858} / T^{1858}\right)$ analysis}

The method used for this analysis was adapted from Lindh et al. [16]. Using primers designed by Lindh et al. [16], EcoNI restriction site would be created when PCR amplification on $\mathrm{T}^{1858}$ variant was performed. Amplification with $\mathrm{C}^{1858}$ variant as the template would not produce the restriction site. Subsequently, PCR products were digested with EcoNI (New England Biolabs) and observed on $2.0 \%$ agarose gel (Promega). $\mathrm{T}^{1858}$ variant would produce $20 \mathrm{bp}$ and $190 \mathrm{bp}$ restriction products while $C^{1858}$ variant would be undigested and remained at $210 \mathrm{bp}$.

\section{Precore stop codon mutations (TGGG $\rightarrow$ T $\underline{A} G)$ analysis}

The method for this analysis was adapted from Lindh et al. [13]. This method was based on creation of Bsu36I restriction site on the PCR product if precore stop codon mutation (TAG) was present. The PCR product amplified from wild-type without the precore mutation (TGG) would not have the restriction site. Subsequently, PCR products were digested with Bsu36I (New England Biolabs) and observed on $2.0 \%$ agarose gel (Promega). Digested DNA products for precore stop codon mutants (TAG) would yield $34 \mathrm{bp}$ and $160 \mathrm{bp}$ while DNA from precore wild-type (TGG) would be undigested and remain at $194 \mathrm{bp}$.

\section{$\mathrm{HBeAg}$ / anti-HBe status determination}

The determinations of the $\mathrm{HBeAg}$ and anti-HBe status were performed on unconcentrated sera using AxSYM® HBe 2.0 (Abbott) and AxSYM ${ }^{\circledR}$ anti-HBe (Abbott) immunoassay kits in the Abbott AxSYM® System (Abbott) automated blood analyzer. 
Quantifications for relative titer levels of both $\mathrm{HBeAg}$ and anti-HBe were performed based on the mean rate of the Index Calibrator provided and calculated as the cutoff rate, $\mathrm{CO}$. The calculation was based on the ratio of the sample signal rate to cutoff rate for each of sample and control (S/CO). A sample was considered to be HBeAg positive when its $\mathrm{S} / \mathrm{CO}$ ratio was $\geq 1.0$ and anti-HBe positive when its $\mathrm{S} / \mathrm{CO}$ ratio was $<1.0$. In the case for anti-HBe, a smaller $\mathrm{S} / \mathrm{CO}$ ratio registered indicated a higher level of the antibody. To better reflect the anti-HBe relative titers, unit for anti-HBe was reported as $\mathrm{CO} / \mathrm{S}$ in this paper.

\section{Statistical analysis}

Chi-square tests were performed between the genotypes, core promoter mutations, codon 15 variants, precore stop codon mutations and $\mathrm{HBeAg} /$ anti-HBe status. Kruskal-Wallis non-parametric ranked sum test was used to analyze the correlation between the genotypes and core promoter mutations with the relative mean HBeAg titer levels. A P value of less than or equal to 0.050 was considered to be significant.

\section{Results}

\section{HBV genotypes observed using nested PCR with type specific primers}

Using this method, $37.7 \%(29 / 77)$ of the samples were found to be infected by HBV genotype B, $19.5 \%$ (15/ 77) by genotype $C, 1.3 \%(1 / 77)$ by genotype $D, 1.3 \%(1 /$ 77) by genotype $\mathrm{E}$ and $3.9 \%$ (3/ 77) by co-infections of genotypes $B$ and $C$ whereas $36.4 \%$ (28/ 77) did not yield any PCR products (Table 1 ).

\section{HBV genotypes observed using PCR-RFLP on the pre-S region}

Using this method, $13.0 \%(10 / 77)$ of the samples were found to be infected by HBV genotype B, $6.5 \%$ (5/ 77) by genotype C, $1.3 \%(1 / 77)$ by co-infections of genotypes $B$ and $C$ (Table 1$)$. Nine sera $(11.7 \%)$ yielded low HBV-DNA PCR products where genotypes could not be determined while three sera $(3.9 \%)$ produced unique RFLP patterns that did not correspond to any RFLP patterns with known genotypes as observed by Lindh et al. [14]. $63.6 \%(49 / 77)$ of the samples did not yield any HBV-DNA PCR products.

Table 1: The genotypes determined by the two different methods

\begin{tabular}{|c|c|c|c|c|c|c|c|c|c|}
\hline \multirow{2}{*}{$\begin{array}{c}\text { Metho } \\
\text { ds } \\
\text { used }\end{array}$} & \multicolumn{8}{|c|}{ Genotypes Determined by the different methods used } & \multirow{2}{*}{$\begin{array}{c}\text { Tot } \\
\text { al }\end{array}$} \\
\hline & B & $\mathrm{C}$ & $\mathrm{D}$ & $\mathrm{E}$ & $\begin{array}{l}\mathrm{B} \text { and } \mathrm{C} \\
\text { co- } \\
\text { infectio } \\
\text { ns }\end{array}$ & $\begin{array}{c}\text { Low } \\
\text { PCR } \\
\text { product } \\
\mathrm{s}^{*}\end{array}$ & $\begin{array}{c}\text { Untypabl } \\
\mathrm{e}^{+}\end{array}$ & $\begin{array}{c}\text { PCR } \\
\text { negati } \\
\text { ve }\end{array}$ & \\
\hline $\begin{array}{l}\text { Naito } \\
\text { et al. } \\
(2001)\end{array}$ & $\begin{array}{c}29 \\
(37.7 \\
\%)\end{array}$ & $\begin{array}{c}15 \\
(19.5 \\
\%)\end{array}$ & $\begin{array}{c}1 \\
(1.3 \\
\%)\end{array}$ & $\begin{array}{c}1 \\
(1.3 \\
\%)\end{array}$ & $\begin{array}{c}3 \\
(3.9 \%)\end{array}$ & - & - & $\begin{array}{c}28 \\
(36.4 \% \\
)\end{array}$ & 77 \\
\hline $\begin{array}{l}\text { Lindh } \\
\text { et al. } \\
\text { (1998) }\end{array}$ & $\begin{array}{c}10 \\
(13.0 \\
\%)\end{array}$ & $\begin{array}{c}5 \\
(6.5 \% \\
)\end{array}$ & - & - & $\begin{array}{c}1 \\
(1.3 \%)\end{array}$ & $\begin{array}{c}9 \\
(11.7 \%)\end{array}$ & $\begin{array}{c}3 \\
(3.9 \%)\end{array}$ & $\begin{array}{c}49 \\
(63.6 \% \\
)\end{array}$ & 77 \\
\hline
\end{tabular}

* PCR product yield low thus genotype could not be determined accurately. + Genotype untypable due to unique RFLP pattern produced that did not correspond to any known genotyped RFLP pattern as observed by Lindh et al. [14].

\section{Overall genotypes observed using the two genotyping methods above}

Combining the results from both genotyping methods, the prevalence were $56.9 \%(29 / 51)$ for genotype B, $341.4 \%$ (16/51) for genotype C, $2.0 \%$ (1/ 51) each for genotypes D and E respectively (Table 2). Four of the sera $(7.8 \%)$ were co-infected by genotypes B and C.

Table 2: Combination of genotyping results determined using methods developed by Lindh et al. [14] and Naito et al. [20]

\begin{tabular}{|c|c|c|c|c|c|c|}
\hline & \multicolumn{6}{|c|}{ Genotypes } \\
\cline { 2 - 7 } & B & C & D & E & B and C* & Total \\
\hline Number of samples & 29 & 16 & 1 & 1 & 4 & 51 \\
& $(56.9 \%)$ & $(31.4 \%)$ & $(2.0 \%)$ & $(2.0 \%)$ & $(7.8 \%)$ & \\
\hline
\end{tabular}

* Genotypes B and C co-infections. This included a sample that was determined to be genotype $C$ when using method developed by Naito et al. [20] but was determined to be co-infected by genotypes $\mathrm{B}$ and $\mathrm{C}$ when method developed by Lindh et al. [14] was used.

\section{Core promoter mutations $\left(A^{1762} G^{1764} \rightarrow T^{1762} A^{1764}\right)$}

Of the 77 sera analyzed, it was observed that 53 sera $(68.8 \%)$ were infected by $\mathrm{A}^{1762} \mathrm{G}^{1764}$ wild-type virus while $11(14.3 \%)$ by $\mathrm{T}^{1762} \mathrm{~A}^{1764}$ mutants. Seven $(9.1 \%)$ of the sera were found to be co-infected by both $A^{1762} \mathrm{G}^{1764}$ wild-type and $\mathrm{T}^{1762} \mathrm{~A}^{1764}$ mutant. Six sera did not yield any PCR product. Statistical analysis between the genotypes $\mathrm{B}$ and $C$ with $\mathrm{A}^{1762} \mathrm{G}^{1764}$ wild-type, $\mathrm{T}^{1762} \mathrm{~A}^{1764}$ mutants and coinfections by $\mathrm{A}^{1762} \mathrm{G}^{1764}$ wild-type and $\mathrm{T}^{1762} \mathrm{~A}^{1764}$ mutants gave a $\mathrm{P}$ value of 0.054 which was very closed to being significant (Table 3).

Table 3: Distribution of genotypes $\mathrm{B}$ and $\mathrm{C}$ with core promoter mutations and codon 15 variants

\begin{tabular}{|c|c|c|c|c|c|}
\hline Genotypes & \multicolumn{2}{|c|}{ Core promoter mutations } & \multicolumn{2}{c|}{$\begin{array}{c}\text { Codon } 15 \\
\text { variants }\end{array}$} \\
\cline { 2 - 6 } & $\begin{array}{c}\mathrm{A}^{1762} \mathrm{G}^{1764} \text { wild- } \\
\text { type }\end{array}$ & $\begin{array}{c}\mathrm{T}^{1762} \mathrm{~A}^{1764} \\
\text { mutant }\end{array}$ & $\begin{array}{c}\text { Co- } \\
\text { infections }\end{array}$ & $\mathrm{T}^{1858}$ & $\mathrm{C}^{1858}$ \\
\hline $\mathrm{B}$ & $\begin{array}{c}20 \\
(71.4 \%)\end{array}$ & $\begin{array}{c}2 \\
(7.1 \%)\end{array}$ & $\begin{array}{c}6 \\
(21.4 \%)\end{array}$ & $\begin{array}{c}16 \\
(84.2 \\
\%)\end{array}$ & $\begin{array}{c}(15.8 \\
\%)\end{array}$ \\
\hline $\mathrm{C}$ & 12 & 4 & - & 8 & 3 \\
& $(75.0 \%)$ & $(25.0 \%)$ & & $\begin{array}{c}72.7 \\
\%)\end{array}$ & $\left.\begin{array}{c}27.3 \\
\%\end{array}\right)$ \\
\hline
\end{tabular}

Note: samples that were co-infected by genotypes B and C were not included.

Codon 15 variants $\left(\mathbf{C}^{\mathbf{1 8 5 8}} / \mathbf{T}^{\mathbf{1 8 5 8}}\right)$

Of the 77 sera, 46 of them yielded PCR products and were analyzed for the codon 15 variants. The prevalence of codon 15 variants was found to be $42.9 \%$ (33/ 77) for $\mathrm{T}^{1858}$ variant and $16.9 \%(13 / 77)$ for $\mathrm{C}^{1858}$ variant. No correlation was found between genotypes $\mathrm{B}$ and $\mathrm{C}$ with $\mathrm{C}^{1858} / \mathrm{T}^{1858}$ variants $(\mathrm{P}=0.45)$ (Table 3$)$.

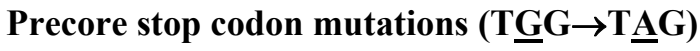

$71(92.2 \%)$ of the sera yielded PCR products with all being TGG wild-type. The rest did not yield any PCR products.

\section{HBeAg/ anti-HBe status}

It was observed that $42.9 \%(33 / 77)$ of the sera were HBeAg positive while $54.5 \%(42 / 77)$ of the sera were anti-HBe positive. Two sera $(2.6 \%)$ were found to be positive for both $\mathrm{HBeAg}$ and anti-HBe. Chi-square test between genotypes $\mathrm{B}$ and $\mathrm{C}$ with $\mathrm{HBeAg} /$ anti-HBe status revealed no significant difference $(\mathrm{P}=0.34)$ (Table 4$)$. This was also true for core promoter mutations $\left(A^{1762} G^{1764}\right.$ wild-type, $\mathrm{T}^{1762} \mathrm{~A}^{1764}$ mutants and co-infections) with the HBeAg/ anti-HBe status $(\mathrm{P}=0.77)$ (Table 5). 
Table 4: Distribution of genotypes $\mathrm{B}$ and $\mathrm{C}$ with $\mathrm{HBe} /$ anti-HBe status

\begin{tabular}{|c|c|c|}
\hline Genotypes & HBe & Anti-HBe \\
\hline B & $\begin{array}{c}15 \\
(51.7 \%)\end{array}$ & $\begin{array}{c}14 \\
(48.3 \%)\end{array}$ \\
\hline C & $\begin{array}{c}10 \\
(66.7 \%)\end{array}$ & $\begin{array}{c}5 \\
(33.3 \%)\end{array}$ \\
\hline
\end{tabular}

Note: samples that were co-infected with genotypes B and C were not included. This also applied to samples with positivity for both $\mathrm{HBe}$ and anti-HBe.

Table 5: Distribution of core promoter mutations with $\mathrm{HBe} /$ anti-HBe status

\begin{tabular}{|c|c|c|c|}
\hline Core promoter mutations & \multicolumn{2}{|c|}{$\mathrm{HBe}$} & Anti-HBe \\
\cline { 2 - 4 } & $\mathrm{n}$ & $\mathrm{S} / \mathrm{CO}^{*}$ & $\mathrm{n}$ \\
\hline $\mathrm{A}^{1762} \mathrm{G}^{1764}$ wild-type & 23 & $217.0 \pm 123.7$ & 30 \\
& $(43.4 \%)$ & & $(56.6 \%)$ \\
\hline $\mathrm{T}^{1762} \mathrm{~A}^{1764}$ mutant & $5 \%$ & $108.1 \pm 100.2$ & 6 \\
& $(45.5 \%)$ & & $(54.5 \%)$ \\
\hline Co-infections & $\begin{array}{c}4 \% \\
(57.1 \%)\end{array}$ & $187.7 \pm 124.7$ & 3 \\
& & $(42.9 \%)$ \\
\hline
\end{tabular}

* Reported as mean \pm standard deviation.

\section{$\mathrm{HBeAg}$ / anti-HBe relative titer levels}

The relative mean titer for $\mathrm{HBeAg}$ was 195.9 S/ CO with standard deviation of 123.5. Categorically, for core promoter mutations status, $\mathrm{A}^{1762} \mathrm{G}^{1764}$ wild-type, $\mathrm{T}^{1762} \mathrm{~A}^{1764}$ mutants and co-infections had relative mean titer levels of $217.0 \pm 123.7 \mathrm{~S} / \mathrm{CO}, 108.1 \pm 100.2 \mathrm{~S} / \mathrm{CO}$ and $184.7 \pm 124.7$ S/ CO respectively (Table 5). However, a Kruskal-Wallis test between the HBeAg relative titer levels of the core promoter mutations status did not reveal any significant difference $(\mathrm{P}=0.27)$. No comparison could be made for precore stop codon mutations as no TAG was detected in this study. The relative mean titer observed for anti-HBe was $12.7 \mathrm{CO} / \mathrm{S}$ with standard deviation of $14.7 \mathrm{CO} / \mathrm{S}$. The high standard deviation seen was due to a single outlier with very high relative titer of $100.0 \mathrm{CO} / \mathrm{S}$ when compared with others.

\section{Discussion}

From the comparisons of the observations of HBV genotypes using the two above methods, it could be deduced that the genotyping method using nested PCR with type specific primers was more sensitive than PCRRFLP on the pre-S region. There was overall consistency between the genotypes observed using nested PCR with type specific primers with PCR-RFLP on the pre-S region. No different genotype was observed for any one particular sample except for the cases involving coinfections by genotypes $\mathrm{B}$ and $\mathrm{C}$. The genotypes $\mathrm{B}$ and $\mathrm{C}$ co-infection observed using PCR-RFLP on the pre-S region was found to be infected only by genotype $C$ when nested PCR with type specific primers was used. Comparison could not be made for the genotypes B and C co-infections observed using nested PCR with type specific primers as no PCR product was obtained for these particular samples when PCR-RFLP on the pre-S region was used. We attempted to verify two of the three co-infections produced by the nested PCR technique through cloning and sequencing but we only managed to obtain singular genotypic infections for every each of them (data not shown). The single co-infection sample produced by the PCR-RFLP technique was checked using cloning and restriction analysis with AvaII and DpnII. However, we only managed to verify for the presence of genotype $C$ infection in all the clones screened (data not shown). The reason for these observations could be attributed to the small clone numbers we had used for sequencing and the single genotypes observed might be the predominant species. The three un-typed RFLP patterns observed using PCR-RFLP on the pre-S region were determined to be of one genotype $B$ and two genotypes $C$ respectively when the nested PCR with type specific primers was used. These were verified through sequencing of the PCR products produced by the PCR-RFLP technique (data not shown). The low PCR product yields obtained using the PCR-RFLP on the pre-S region could be due to the nature of the technique used where amplification was performed only once. This was in contrast to the nested PCR technique where two rounds of amplifications were performed. In the subsequent statistical tests, co-infections by genotypes $\mathrm{B}$ and $\mathrm{C}$ as well as genotypes $\mathrm{D}$ and $\mathrm{E}$ were excluded from analyses.

Our observation for the prevalence of genotypes was in concordance with those results reported by a few studies $[11,14,23]$. The studies showed that genotypes B and $C$ were more common in the Asia-Pacific regions with genotype $\mathrm{B}$ being more predominant. We had indeed observed that genotypes $\mathrm{B}$ and $\mathrm{C}$ were the main strains infecting HBV carriers in Malaysia with the former being more predominant. However region-wise, this result was different from that reported by Sugauchi et al. [30] who reported that genotype $\mathrm{C}$ was more predominant in the Thai population. In Japan, genotype $C$ was more predominant than genotype B [24]. All these observations followed the trend that genotypes B and $C$ were localized in the Asia-Pacific regions but with varying degree of predominance. Given the same geographic endemicity of genotypes B and C, co-infections by these two genotypes are not surprising. Few other studies had also reported genotypic co-infections [10, 35]. This shows that coinfections could be quite common indeed.

Many studies had shown that the core promoter mutations $\left(\mathrm{A}^{1762} \mathrm{G}^{1764} \rightarrow \mathrm{T}^{1762} \mathrm{~A}^{1764}\right)$ were more common in genotype $C$ than in genotype $B[9,15,25,28]$. The present study did not detect significant difference. Nevertheless, it is interesting to note that the statistical test produced a result which was very close to being significant $(P=0.054)$. Possibly, a significant result could be obtained given a bigger sample size. In some other studies, correlation between genotypes and core promoter mutations was not observed [7, 11]. The conflicting results observed could imply that there might be other factors that are involved in determining the correlation.

Sugauchi et al. [31] had proposed that within genotype $B$, two genotype $B$ subtypes exist namely $B j$ which is found mainly in Japan and Ba which is found in some other Asian countries such as China, Hong Kong, Taiwan, Thailand and Vietnam. The Ba strain has recombination with genotype $\mathrm{C}$ in the precore region and the core gene whereas $\mathrm{Bj}$ strain is without any recombination [31]. They observed that Ba strain had higher prevalence of the core promoter mutations than in Bj strain (33\% vs. $15 \%$ ). This fact might be relevant to our case as the subtypes might influence the observation we had. The observation by Sugauchi et al. [31] has made the subtypes $\mathrm{Ba}$ and $\mathrm{Bj}$ as another variable to look at in the correlation analysis between genotypes and core promoter mutations. The varying proportions of the $\mathrm{Ba}$ and $\mathrm{Bj}$ subtypes within genotype $B$ samples might influence the correlation outcome of the core promoter mutations with 
genotype B. As we do not know the proportions of Ba and $\mathrm{Bj}$ subtypes in our genotype B samples, thus the core promoter mutations we observed might be influenced by the varying degree of proportions of $\mathrm{Ba}$ and $\mathrm{Bj}$ subtypes. Besides that, the co-infections of both $A^{1762} G^{1764}$ wild-type and $T^{1762} \mathrm{~A}^{1764}$ mutants in our genotype $B$ samples could be attributed by co-infections of $\mathrm{Ba}$ and $\mathrm{Bj}$ subtypes, where one subtype contributed the $\mathrm{A}^{1762} \mathrm{G}^{1764}$ wild-type and the other subtype contributed the core promoter mutation. It is interesting to note that only genotype $\mathrm{B}$ samples had coinfections of both $A^{1762} \mathrm{G}^{1764}$ wild-type and $\mathrm{T}^{1762} \mathrm{~A}^{1764}$ mutants but this phenomenon was not observed for genotype $\mathrm{C}$ samples.

Several studies revealed that core promoter mutations might be influenced by the existence of precore stop codon mutations where an inverse relationship between core promoter mutations and precore stop codon mutations was seen $[5,6]$. However, we observed otherwise, where low numbers of core promoter mutations were observed and no precore stop codon mutations were observed. Thus, it could be that core promoter mutations might also be influenced by factors such as geography or ethnicity, hence the prevalence of core promoter mutations were not based on genotypes alone. Although Malaysia has a multi-ethnic population (mainly inhabited by the Malays, Chinese and Indians in respective order of proportions), we were not able to perform the relationships with the ethnics due to incomplete data of the ethnic origins of our samples.

Associations between codon 15 variants $\left(\mathrm{C}^{1858} / \mathrm{T}^{1858}\right)$ and genotypes had been mentioned. The $\mathrm{C}^{1858}$ variant was closely associated with genotypes $\mathrm{A}, \mathrm{F}$ and $\mathrm{H}$ as well as genotype $C$ but not with genotypes $B, D$ and $E[2,3,12]$. In our case, although $15.8 \%$ (3/ 19) of the genotype B with positive results for codon 15 analysis was $\mathrm{C}^{1858}$ variant, significant difference was not observed $(P=0.45)$. Nevertheless, we still observed a higher prevalence of $\mathrm{C}^{1858}$ variants in genotype $\mathrm{C}$ samples than in genotype $\mathrm{B}$ $(27.3 \%$ vs. $15.8 \%)$.

In this study, analysis on codon 28 at the precore region revealed that all the sera were infected by TGG wild-type. A few studies had observed certain correlations between genotypes and precore stop codon mutations $(\mathrm{TGG} \rightarrow \mathrm{TAG})[6,7,15]$. Within the same geographic region, Huy et al. [9] reported that genotype B was linked to TAG mutation. However, conflicting results on the correlation between genotypes and precore stop codon mutations (TGG $\rightarrow$ TAGG) had been reported elsewhere. Orito et al. [25] observed no significant difference between the predispositions to TAG mutation development between genotypes $B$ and $C$. Besides that, Kidd-Ljunggren et al. [11] did not observe any such correlation in samples of various geographic origins. As no TAG mutation was observed in our case, this study was in contrast to that of Huy et al. [9] where in our case, TAG mutation was predisposed by genotype $B$ even though large number of genotype $B$ samples was observed $(n=28)$. The failure to observe any TAG mutation in our case might be significant by itself. This is because various other studies reported at least some precore stop codon mutations in their study $[6,7,9,11,15,25]$. Thus, it could be possible that TAG mutations are influenced by other factors as well such as geography, ages and ethnics. Besides that, genotype B subtypes might play a role here. Although no significant difference was observed, Sugauchi et al. [31] reported that TAG mutations were more frequent in $\mathrm{Bj}$ than Ba subtype ( $50 \%$ vs. $18 \%$ ). Therefore, there is a possibility that there is a higher prevalence of Ba subtype in our samples which leads to the absence of any TAG mutants. However, many other Asian countries such as China, Thailand and Vietnam where high prevalence of Ba was reported, still observed the occurrences of TAG mutants [31].

Based on the secondary stem loop structure of the pgRNA, theoretically, there should be correlation between nucleotide at 1858 in codon 15 with nucleotide at 1896 in precore region at codon 28 of the precore/ core gene [33]. No correlation analysis could be made in our study as no TAG mutation was observed. Nevertheless, our result fitted the general concept in that no TAG mutation should occur together with $\mathrm{C}^{1858}$ variant as we did not observe the co-existence of $\mathrm{C}^{1858}$ variants with TAG mutations.

No significant correlation was observed between $\mathrm{HBeAg}$ / anti-HBe status with genotypes B and C. This is in contrast to several studies which reported that patients infected by HBV genotype $B$ were more prone to be HBeAg negativity than those infected by genotype $C[15$, 28]. On a regional basis, this study was also in contrast to that reported by Sugauchi et al. [30] where in a Thai population, they observed that HBeAg positivity were more prevalent in sera infected by genotype $C$ than by genotype B. Some studies had shown that patients infected by genotype $C$ experienced longer period of being in $\mathrm{HBeAg}$ positivity with delayed seroconversion to anti-HBe status [15, 24]. This might explain the reason why correlation was not observed in this study. If the above statement held true, the proportion of $\mathrm{HBeAg} /$ anti-HBe could depend on the timing of sample collection as well. This could complicate the matter in hands as one would seldom know when infection was initiated.

The emergence of anti-HBe immunity puts selective pressure against the HBV that express $\mathrm{HBeAg}$. Hepatocytes harbouring the wild-type HBV would be eliminated due to the display of HBeAg on the cell membrane which would be targeted by the immune response. Thus mutants that lack or have decreased HBeAg expression would evade the immune response and survive [26]. The observation of co-infections by both $\mathrm{A}^{1762} \mathrm{G}^{1764}$ wild-type and $\mathrm{T}^{1762} \mathrm{~A}^{1764}$ mutants could indicate an ongoing selection process, which given time, could see the total exclusion of the wild-type. Regrettably, we were not able to follow up on the cases studied for a longer period of time. As the HBV were under selective pressure, they might evolve fully into mutants sometime in the future.

Statistical significant difference was not observed for $\mathrm{HBeAg} /$ anti-HBe status with core promoter mutations $\left(\mathrm{A}^{1762} \mathrm{G}^{1764} \rightarrow \mathrm{T}^{1762} \mathrm{~A}^{1764}\right)$. This was in contrast to some observations reported where core promoter mutations $\left(\mathrm{A}^{1762} \mathrm{G}^{1764} \rightarrow \mathrm{T}^{1762} \mathrm{~A}^{1764}\right)$ were linked to $\mathrm{HBeAg}$ seroconversion to anti-HBe $[8,22]$. In concordance to this study, a few reports did not find any correlation between the core promoter mutations with $\mathrm{HBeAg} /$ anti-HBe status $[7,15,25,32]$. We observed a substantial number of $\mathrm{T}^{1762} \mathrm{~A}^{1764}$ mutants infecting sera with $\mathrm{HBeAg}$ positivity. This phenomenon could be explained by the fact that the occurrence of $\mathrm{T}^{1762} \mathrm{~A}^{1764}$ mutation only decreased the production of $\mathrm{HBeAg}$, not totally abolishing it. Therefore, the presence of $\mathrm{T}^{1762} \mathrm{~A}^{1764}$ mutants does not necessarily mean the absence of HBeAg detection. Many other reports 
also observed the occurrences of $\mathrm{T}^{1762} \mathrm{~A}^{1764}$ mutants in HBeAg positive sera $[5,7,8,22,32]$. Analysis between core promoter mutations with relative mean titer levels did not show any significant correlation. Possible reason for this was that $\mathrm{HBeAg}$ expression reduction made by $\mathrm{T}^{1762} \mathrm{~A}^{1764}$ mutation alone was quite low (by about $20 \%$ ) and was not enough to decrease the HBeAg level to a point where statistical significance was observed [26]. This could explain the observation for one sample where a relatively high HBeAg titer (273.8 S/ CO) could be observed in the presence of $\mathrm{T}^{1762} \mathrm{~A}^{1764}$ mutation. It could be that the HBeAg expression by the virus was only reduced minimally. Besides that, $\mathrm{T}^{1762} \mathrm{~A}^{1764}$ mutants could become predominant even before the emergence of anti-HBe especially during the late $\mathrm{HBeAg}$ positive phase $[5,26]$. Other samples infected by $\mathrm{T}^{1762} \mathrm{~A}^{1764}$ mutants had considerably lower HBeAg titer levels which could be attributed to mutations occurring elsewhere. Parekh et al. [26] showed that mutations at nucleotides 1753 and 1766 in addition to the $\mathrm{T}^{1762} \mathrm{~A}^{1764}$ mutation could decrease HBeAg expression by up to $80 \%$. Mutations downstream of the precore start codon could also decrease $\mathrm{HBeAg}$ translation [1]. We also detected anti-HBe in sera infected by HBV without mutations at both the core promoter and precore stop codon mutations. There were possibilities that other mutations occurred that abolish the $\mathrm{HBeAg}$ production such as mutation at the precore start codon or TAA stop mutation at codon 2 [16]. This could be the case for one sample which recorded a relatively very high antiHBe level (100.0 CO/ S) but still being a wild-type. For other cases, it could also be that enough wild-type viruses survived the weak onslaught of the immune system and be detected in the study. Our result showed that the average relative anti-HBe titer was quite low but we must admit that there was no benchmark that could be taken as norm. However, the observation that a relative titer of $100.0 \mathrm{CO} / \mathrm{S}$ detected in this study indicated that anti-HBe could reach quite high a level indeed.

Although we observed that $54.5 \%(42 / 77)$ of our samples were HBeAg negative, we were not able to perform a more detailed analysis on the HBeAg-negative chronic patients. This was because we had difficulty in discerning between HBeAg-negative chronic patients with inactive HBsAg carriers, especially when most of our samples consisted of blood donors. The criteria for being a HBeAg-negative chronic is that a patient has recurrence of HBsAg for more than 6 months, negative for $\mathrm{HBeAg}$, positive for anti-HBe, HBV DNA presence of more than $10^{5}$ to $10^{6}$ copies / mL, increased alanine aminotransferase (ALT) level with histological liver injury. For being an inactive HBsAg carrier, the patient is negative for HBeAg, positive for anti-HBe, has undetectable or low HBV DNA level, repeatedly normal ALT with none or minimal histological liver injury [18]. With these criteria in hand, we could not categorize the samples accordingly due to incomplete data on the HBV DNA levels, ALT levels and histological liver injuries. Many blood donors were unaware that they were infected with HBV until they were found positive for HBsAg during routine screening. Some blood donors might have HBeAg-negative chronic hepatitis B infections without knowing it.

Another study was carried out by us on HBV DNA levels in 66 sera samples using real-time PCR (data not shown). Conflicting results had been reported on the correlations between the genotypes with HBV DNA levels
$[30,36]$. We found that genotypes $B$ and $C$ were not significantly associated with HBV DNA levels but individuals infected with genotype $C$ were inclined towards greater than $10^{6}$ copies/ $\mathrm{mL}$ (high viral load). Besides that, it has been suggested that the core promoter mutations might favour more efficient viral replication which may imply a higher HBV DNA level [15, 19]. However, we observed that the core promoter mutations were not significantly linked to HBV DNA levels which were in concordance to several reports [25, 34]. Interestingly, samples co-infected by both $\mathrm{A}^{1762} \mathrm{G}^{1764}$ wildtype and ${ }^{1762} \mathrm{~A}^{1764}$ mutants had higher HBV DNA levels. However, one must treat this result cautiously as the phase of HBV infection at which the sera samples were obtained would affect the HBV DNA level concentrations.

In conclusion, the predominant HBV genotypes in the Malaysian carriers was genotype $B$ followed by genotype C. No significant correlations were observed between HBV genotypes, core promoter mutations $\left(\mathrm{A}^{1762} \mathrm{G}^{1764} \rightarrow \mathrm{T}^{1762} \mathrm{~A}^{1764}\right)$ and HBeAg/ anti-HBe status. Conflicting results regarding the correlations had been reported. The correlations of these variables could be influenced by other various factors which had thus made any concrete correlation to be elusive so far. One possible major influence could be due to the genotype B subtypes $\mathrm{Ba}$ and $\mathrm{Bj}$. Hence, it would be interesting to do further research along this path.

\section{Acknowledgement}

We thank Z. Mazlam of Ampang Putri Specialist Hospital/ Hospital Universiti Kebangsaan, Malaysia and N. Thanaletchimy of Tengku Ampuan Rahimah Hospital, Klang, Malaysia for the provision of the sera samples. We also thank K. L. Chan and the staff of Sunway Medical Center, Malaysia for provision of samples, permission and technical assistance in the use/help of their diagnostic facilities.

\section{Conflict of interest}

The authors have declared that no conflict of interest exists.

\section{References}

1. Ahn S, Kramvis A, Kawai S, Spangenberg H, Li J, Kimbi G, Kew M, Wands J, Tong S. Sequence variation upstream of precore translation initiation codon reduces hepatitis $B$ virus e antigen production. Gastroenterology 2003; 125(5):1370-1378.

2. Alestig E, Hannoun C, Horal P, Lindh M. Phylogenetic origin of hepatitis B virus strains with precore C-1858 variant. J Clin Microbiol 2001; 39(9):3200-3203.

3. Arauz-Ruiz P, Norder H, Robertson BH, Magnius LO. Genotype H: a new Amerindian genotype of hepatitis B virus revealed in Central America. J Gen Virol 2002; 83(8):2059-2073.

4. Carman WF, Jacyna MR, Hadziyannis S, Karayiannis P, McGarvey MJ, Makris A, Thomas HC. Mutation preventing formation of hepatitis B e antigen in patients with chronic hepatitis B infection. Lancet 1989; 2(8663):588-591.

5. Chan HL, Hussain M, Lok AS. Different hepatitis B virus genotypes are associated with different mutations in the core promoter and precore regions during hepatitis B e antigen seroconversion. Hepatology 1999 29(3):976-984.

6. Chu CJ, Keeffe EB, Han SH, Perrillo RP, Min AD, Soldevila-Pico C, Carey W, Brown RS Jr, Luketic VA, Terrault N, Lok AS; U.S. HBV Epidemiology Study Group. Prevalence of HBV precore/core promoter variants in the United States. Hepatology 2003; 38(3):620628.

7. França PH, González JE, Munné MS, Brandão LH, Gouvea VS, Sablon E, Vanderborght BO. Strong association between genotype F 
and hepatitis B Virus (HBV) e antigen-negative variants among HBV-infected argentinean blood donors. J Clin Microbiol 2004; 42(11): 5015-5021.

8. Hussain M, Chu CJ, Sablon E, Lok AS. Rapid and sensitive assays for determination of hepatitis B virus (HBV) genotypes and detection of $\mathrm{HBV}$ precore and core promoter variants. J Clin Microbiol 2003; 41(8): 3699-3705.

9. Huy TT, Ushijima H, Quang VX, Ngoc TT, Hayashi S, Sata T, Abe $\mathrm{K}$. Characteristics of core promoter and precore stop codon mutants of hepatitis B virus in Vietnam. J Med Virol 2004; 74(2):228-236.

10. Kao JH, Chen PJ, Lai MY, Chen DS. Clinical and virological aspects of blood donors infected with hepatitis B virus genotypes B and C. J Clin Microbiol 2002; 40(1): 22-25.

11. Kidd-Ljunggren K, Myhre E, Blackberg J. Clinical and serological variation between patients infected with different Hepatitis B virus genotypes. J Clin Microbiol 2004; 42(12):5837-5841.

12. Li JS, Tong SP, Wen YM, Vitvitski L, Zhang O, Trepo C. Hepatitis B virus genotype $\mathrm{A}$ rarely circulates as an HBe-minus mutant: possible contribution of a single nucleotide in the precore region. J Virol 1993; 67(9):5402-5410.

13. Lindh M, Furuta Y, Ljunggren KK, Norkrans G, Horal P. Detection of hepatitis $\mathrm{B}$ virus precore TAG mutant by an amplificationcreated restriction site method. J Infect Dis 1995; 171(1):194-197.

14. Lindh M, Gonzalez JE, Norkrans G, Horal P. Genotyping of hepatitis $\mathrm{B}$ virus by restriction pattern analysis of a pre-S amplicon. J Virol Methods 1998; 72(2):163-174.

15. Lindh M, Hannoun C, Dhillon AP, Norkrans G, Horal P. Core promoter mutations and genotypes in relation to viral replication and liver damage in East Asian hepatitis B virus carriers. J Infect Dis 1999; 179(4):775-782.

16. Lindh M, Horal P, Dhillon AP, Furuta Y, Norkrans G. Hepatitis B virus carriers without precore mutations in hepatitis $B$ e antigennegative stage show more severe liver damage. Hepatology 1996; 24(3):494-501.

17. Lok AS, Akarca U, Greene S. Mutations in the pre-core region of hepatitis B virus serve to enhance the stability of the secondary structure of the pre-genome encapsidation signal. Proc Natl Acad Sci U S A 1994; 91(9):4077-4081.

18. Lok ASF, McMahon BJ. Chronic hepatitis B. Hepatology 2001; 34(6):1225-1241.

19. Moriyama K, Okamoto H, Tsuda F, Mayumi M. Reduced precore transcription and enhanced core-pregenome transcription of hepatitis B virus DNA after replacement of the precore-core promoter with sequences associated with e antigen-seronegative persistent infections. Virology 1996; 226(2):269-280.

20. Naito H, Hayashi S, Abe K. Rapid and specific genotyping system for hepatitis B virus corresponding to six major genotypes by PCR using type-specific primers. J Clin Microbiol 2001; 39(1):362-364.

21. Norder H, Hammas B, Lee SD, Bile K, Courouce AM, Mushahwar IK, Magnius LO. Genetic relatedness of hepatitis B viral strains of diverse geographical origin and natural variations in the primary structure of the surface antigen. J Gen Virol 1993; 74(7):1341-1348.

22. Okamoto H, Tsuda F, Akahane $Y$, Sugai $Y$, Yoshiba M, Moriyama K, Tanaka T, Miyakawa Y, Mayumi M. Hepatitis B virus with mutations in the core promoter for an e antigen-negative phenotype in carriers with antibody to e antigen. J Virol 1994; 68(12):8102-8110.

23. Okamoto H, Tsuda F, Sakugawa H, Sastrosoewignjo RI, Imai M, Miyakawa Y, Mayumi M. Typing hepatitis B virus by homology in nucleotide sequence: comparison of surface antigen subtypes. J Gen Virol 1988; 69(10):2575-2583.

24. Orito E, Ichida T, Sakugawa H, Sata M, Horiike N, Hino K, Okita K, Okanoue T, Iino S, Tanaka E, Suzuki K, Watanabe H, Hige S, Mizokami M. Geographic distribution of hepatitis B virus (HBV) genotype in patients with chronic HBV infection in Japan. Hepatology 2001; 34(3):590-594.

25. Orito E, Mizokami M, Sakugawa H, Michitaka K, Ishikawa K, Ichida T, Okanoue T, Yotsuyanagi H, lino S. A case-control study for clinical and molecular biological differences between hepatitis B viruses of genotypes B and C. Japan HBV Genotype Research Group. Hepatology 2001; 33(1):218-223.

26. Parekh S, Zoulim F, Ahn SH, Tsai A, Li J, Kawai S, Khan N, Trepo C, Wands J, Tong S. Genome replication, virion secretion, and e antigen expression of naturally occurring hepatitis B virus core promoter mutants. J Virol 2003; 77(12):6601-6612.

27. Petzold DR, Tautz B, Wolf F, Drescher J. Infection chains and evolution rates of hepatitis $\mathrm{B}$ virus in cardiac transplant recipients infected nosocomially. J Med Virol 1999; 58(1):1-10.

28. Sakurai M, Sugauchi F, Tsai N, Suzuki S, Hasegawa I, Fujiwara K, Orito E, Ueda R, Mizokami M. Genotype and phylogenetic characterization of hepatitis B virus among multi-ethnic cohort in Hawaii. World J Gastroenterol 2004; 10(15):2218-2222.

29. Stuyver L, De Gendt S, Van Geyt C, Zoulim F, Fried M, Schinazi RF, Rossau R. A new genotype of hepatitis $B$ virus: complete genome and phylogenetic relatedness. J Gen Virol 2000; 81(1):67-74.

30. Sugauchi F, Chutaputti A, Orito E, Kato H, Suzuki S, Ueda R, Mizokami M. Hepatitis B virus genotypes and clinical manifestation among hepatitis B carriers in Thailand. J Gastroenterol Hepatol 2002; 17(6):671-676.

31. Sugauchi F, Orito E, Ichida T, Kato H, Sakugawa H, Kakumu S, Ishida T, Chutaputti A, Lai CL, Gish RG, Ueda R, Miyakawa Y, Mizokami M. Epidemiologic and virologic characteristics of hepatitis B virus genotype B having the recombination with genotype C. Gastroenterology 2003; 124(4):925-932.

32. Takahashi K, Aoyama K, Ohno N, Iwata K, Akahane Y, Baba K, Yoshizawa H, Mishiro S. The precore/core promoter mutant (T1762A1764) of hepatitis B virus: clinical significance and an easy method for detection. J Gen Virol 1995; 76(12):3159-3164.

33. Tong SP, Li JS, Vitvitski L, Kay A, Treépo C. Evidence for a basepaired region of hepatitis $\mathrm{B}$ virus pregenome encapsidation signal which influences the patterns of precore mutations abolishing HBe protein expression. J Virol 1993; 67(9):5651-5655.

34. Yoo BC, Park JW, Kim HJ, Lee DH, Cha YJ, Park SM. Precore and core promoter mutations of hepatitis $\mathrm{B}$ virus and hepatitis $\mathrm{B}$ e antigen-negative chronic hepatitis B in Korea. J Hepatol 2003; 38(1) :98-103.

35. Yotsuyanagi H, Okuse C, Yasuda K, Orito E, Nishiguchi S, Toyoda J, Tomita E, Hino K, Okita K, Murashima S, Sata M, Hoshino H, Miyakawa Y, Iino S; Japanese Acute Hepatitis B Group. Distinct geographic distributions of hepatitis $B$ virus genotypes in patients with acute infection in Japan. J Med Virol 2005; 77(1):39-46.

36. Yuen MF, Sablon E, Yuan HJ, Wong DKH, Hui CK, Wong BCY, Chan AOO, Lai CL. Significance of hepatitis B genotype in acute exacerbation, HBeAg seroconversion, cirrhosis-Related complications and hepatocellular carcinoma. Hepatology 2003; 37(3):562-567.

37. Yuh $\mathrm{CH}$, Chang YL, Ting LP. Transcriptional regulation of precore and pregenomic RNAs of hepatitis B virus. J Virol 1992; 66(7):40734084 . 